\title{
PARTISIPASI POLITIK PEMILIH PEMULA DALAM PEMILIHAN LEGISLATIF TAHUN 2014 (Studi Pada Masyarakat Adat di Kelurahan Kulaba Kecamatan Pulau Ternate)
}

\author{
Hamis Basahona ${ }^{1}$ dan Syahril Muhammad ${ }^{2}$ \\ ${ }^{1}$ Alumni Prodi Pendidikan Pancasila dan Kewarganegaraan, FKIP Universitas Khairun, Jl. Bandara Baabullah Akehuda \\ Ternate Utara, 97728, Indonesia \\ ${ }^{2}$ Dosen Prodi Pendidikan Pancasila dan Kewarganegaraan, FKIP Universitas Khairun, Jl. Bandara Baabullah Akehuda Ternate \\ Utara, 97728, Indonesia
}

Author Correspondence: hasmawati@yahoo.com

$\begin{array}{ll}\text { Diterima } & : 08-03-2018 . \\ \text { Direvisi } & : 20-03-2018 \\ \text { Dipublikasi } & : \text { 05-04-2018 }\end{array}$

\begin{abstract}
This research is a study of the political participation of new voters in the 2014 legislative elections. The study of indigenous peoples is motivated by the use of local cultural symbols namely "Jou Kasa Ngom Kage" during legislative elections which refers to the obedience, and loyalty of indigenous peoples to the Sultan. The purpose of this research is (1) to find out the attractiveness of the beginner voters to the candidates who fight, (2) to find out the forms of political participation of first-time voters among indigenous peoples and (3) to find out the obstacles that hamper voter political participation beginners in the 2014 legislative elections. This type of research is qualitative research using observation, interview and documentation techniques. The results of this study indicate that (1) political participation of beginner voters in Kulaba subdistrict, Ternate Island in the 2014 legislative elections, still tended to be dominated by the strength and attractiveness of charismatic traditional leaders. (2) the form of political participation of first-time voters in Kulaba Sub-District, Ternate Island as seen from involvement of novice voters in the dissemination of the stages of legislative elections, participation in campaign activities to deliver the vision and mission of political parties as well as the delivery of the vision and mission of candidates for legislative members and their presence in voting rights during elections and"Jou kasa ngom kage" (Ternate Malay) which means Jou'ou or Sultan where the people are there, this is the language of the press (media) which is trying to be manipulated by political actors in the run-up to the elections both legislative elections and Regional head elections with destination forget support from the community in the sultanate's cultural circle not a language that was born together with the birth of the kingdom of the sultan of Ternate. (3) constraints as a barrier to the participation of political voters in determining their voting rights are still influenced by the behavior of some legislative candidates who manipulate custom symbols for their political interests. Other than that there is still a lack of education level for novice voters who do not have a mature attitude in determining their choices as citizens who are free in determining their political choices.
\end{abstract}

Keywords: Political Participation, Beginner Voter, Legislative Election and Kulaba Village

\section{PENDAHULUAN}

Pemilu merupakan salah satu bentuk partisipasi politik sebagai perwujudan dari kedaulatan rakyat, karena pada saat pemilu itulah, rakyat menjadi pihak yang paling menentukan bagi proses politik di suatu negara dengan memberikan suara secara langsung dalam bilik suara. Dari seluruh warga negara yang memiliki hak pilih, terdapat warga negara yang pertama kali ikut serta dalam pemilihan umum, yaitu pemilih pemula (17-21 tahun). Mereka tidak memiliki pengalaman pada pemilihan sebelumnya. Namun, ketiadaan pengalaman bukan berarti mencerminkan keterbatasan menyalurkan aspirasi politik

Menurut Davidson bahwa manifestasi politik lokal dan adat di wilayah-wilayah bekas kesultanan senatiasa mencerminkan manipulasi terhadap tradisi oleh aktor politik yang mencari kepentingan sendiri. Kondisi tersebut menunjukan manivestasi politik dan demokrasi di kalangan masyarakat adat 
masih di dominasi oleh tradisi dan kekuasaan yang berbasis pada figur karismatik dan feodalisme yang belum sepenuhnya menjadi kekuatan dalam mendorong kemajuan pembangunan di bidang politik dan demokratisasi di tingkat lokal. Dari penjelasan di atas menunjukkan bahwa percaturan politik yang berlangsung di tingkat lokal selain dari petinggi-petinggi partai politik yang berupaya dengan menggerakkan seluruh kekuatan mereka dengan menghalalkan segala cara untuk memenangkan pertarungan politik yang ada, Hal yang berbeda dilakukuan oleh aktor-aktor politik lokal dengan memanfaatkan tokoh-tokoh adat yang kharismatik sebgai kekuatan mereka untuk meraih kekuasaan, seperti "Jou Kasa Ngom Kage" yang artinya 'Jou (Sultan) dimana, torang disitu' hal ini biasa terjadi ketika menjelang pemilihan baik itu pilkada maupun pemilihan legislatif.

Bentuk partisipasi yang dilakukan oleh pemilih pemula bentuknya sangat beragam, mulai dari bentuk yang paling sederhana sampai kepada bentuk yang membutuhkan intensitas yang penuh. Mulai dari mengikuti pemberian suara, diskusi politik sampai pada kegiatan kampanye. Bentuk partisipasi politik yang dilakukan oleh pemilih pemula berbeda satu sama lain. Perbedaan ini disebabkan karena adanya perbedaan dalam hal tinggi rendahnya pengetahuan yang diterima, faktor usia, tekanan dari berbagai pihak serta pengalaman. Pemilih pemula adalah warga negara Indonesia yang telah genap berusia 17 tahun atau lebih atau sudah/pernah kawin. syarat-syarat yang harus dimiliki untuk menjadikan seseorang dapat memilih .

Kendala-kendala yang dihadapi pemilih pemula dalam menciptakan peran aktifnya dalam kehidupan politik tidak terlepas dari kendala yang bersifat internal dan eksternal. Kendala internal meliputi faktor usia, kurangnya dana, tuntutan pelajar yang membatasi peran aktif pemilih pemula dalam kehidupan politik, dan faktor yang berkaitan dengan persoalan izin orang tua. Adapun kendala eksternal meliputi konteks kurangnya KPUD Kota Ternate memberikan sosialisasi yang berkaitan dengan pemilihan Kepala Daerah Kota Ternate yang memperhatikan kepentingan pemilih pemula, kurang optimalnya peranan media massa dalam membangun opini publik tentang pentingnya representasi pemilih pemula dalam pemilihan umum khususnya pemilihan wali Kota kepala daerah Kota Ternate, belum adanya jaringan antara organisasi masyarakat, LSM, dan partai-partai politik serta para calon kepala daerah untuk memperhitungkan representasi pemilih pemula, peran sekolah yang menuntut pemilih pemula harus mementingkan akademis pelajaran sekolah dan kurang mendukung peran aktif pemilih pemula dalam bidang politik. Terlepas dari itu dalam kehidupan masyarakat adat terdapat tokoh- tokoh adat yang kharismatik. Oleh karena itu pertanyaan yang diajukan dalam tulisan ini adalah bagaimana bentuk partisipasi politik pemilih pemula dalam pemilihan legislatif tahun 2014 di Kelurahan Kulaba Kecamatan Pulau Ternate.

\section{METODE PENELITIAN}

Penelitian ini menggunakan metode kualitatif naturalistik. Hal ini berdasarkan pertimbangan, bahwa ciri utama dari studi naturalistik adalah: (1) realitas manusia tidak dapat dipisahkan dari konteks latar natural, (2) penggunaan pengetahuan tersembunyi (tacit knowledege), (3) hasil (penelitian) yang dinegosiasikan dan interpretasi antara peneliti dan subjek penelittian, (4) penafsiran atas data bersifat ideolografis atau berlaku khusus, bukan bersifat nomotetis atau mencari generalisasi, dan (5) temuan penelitian bersifat tentatif (Lincoln \& Guba, 1985:187-190). Dengan menggunakan metode kualitatif naturalistik, peneliti harus berinteraksi secara langsung dengan subjek penelitian, dengan tujuan untuk mendapatkan informasi yang akurat, apa adanya, melalui suatu proses observasi dan wawancara.

Penelitian ini dilaksanakan pada pemilih pemula di kalangan masyarakat Adat di Kelurahan Kulaba Kecamatan Pulau Ternate. Alasannya, karena terdapat nilai-nilai adat dan tradisi yang masih cukup kuat, terutama masyarakat yang ada pada lingkaran kultur kesultanan Ternate.Sedangkan waktu penelitian ini dilaksanakan selama 2 bulan yakni sejak tanggal 04 Februari sampai 14 April 2017.

\section{Teknik Pengumpulan dan Analisis Data}


Jenis Penelitian ini adalah kualitatif naturalistik, maka teknik pengumpulan data yang digunakan adalah: (1) Observasi, ialah metode atau cara-cara menganalisis dan mengadakan pencatatan secara sistematis mengenai tingkah laku dengan melihat atau mengamati individu atau kelompok secara langsung (Ngalim Purwanto, 2009); (2) Wawancara, suatu percakapan yang diarahkan pada suatu masalah tertentu dan merupakan proses tanya jawab lisan dimana dua orang atau lebih berhadapan secara fisik; (3) Dokumentasi, yaitu proses pembuktian yang didasarkan atas jenis sumber apapun, baik itu yang bersifat tulisan, lisan, gambar atau arkeologis (Gottschalk, 1986).

Sementara tehnik analisis data dalam penelitan mengunakan pendapat Miles dan Huberman bahwa ada 3 tahapan yang harus dikerjakan dalam menganalisis data penelitian kualitatif, yaitu; (1) Reduksi data merupakan kegiatan merangkum, memilah hal-hal pokok, memfokuskan pada hal-hal yang penting; (2) Paparan data merupakan sekumpulan informasi tersusun dan memberikan kemungkinan dan adanya penarikan kesimpulan dan pengambilan tindakan; (3) Penarikan kesimpulan merupakan hasil penelitian yang menjawab fokus penelitian berdasarkan hasil analisis data.

\section{PEMBAHASAN}

\section{a. Daya Tarik Pemilih Pemula Pada Pemilihan Legislatif Tahun 2014}

Hasil temuan di lapangan menunjukkan bahwa daya tarik pemilih pemula ini dibedakan dalam dua kategori yakni kategori pemilih konvensional dan pemilih non konvensional. Di mana mereka yang dalam kategori konvensional ini mereka adalah aktif yang rata-rata mayoritasnya adalah pelajar yang duduk di bangku SMA dan perguruan tinggi sehingga mereka lebih cenderung pada pendirian mereka dimana mereka memberikan hak politiknya berdasakan dengan tawaran program kerja yang termaktub dalam visi dan misi serta pengalaman yang dimiliki oleh kandidat-kandidat yang ada (Pemilih Konvensional). Lain halnya dengan pemilih non konvensional, dalam hal politik mereka lebih cenderung mengikuti kemauan orang tua, teman serta keluarga.

Selain itu, hasil temuan di lapangan juga menunjukkan bahwa kolano merupakan pemimpin adat yang sakral yang diyakini sebagai wakil dari Tuhan atau disebut sebagai, "primus interpares" atau pemimpin yang kharismatik itu adalah pemimpin yang terpercaya dan dihormati oleh rakyatnya. Di Kota Ternate dan bahkan sampai pada dataran halmahera kolano itu sangat dihormati dan dihargai sebagai pemimpin yang Agung. olehnya itu dalam hal politik, ada aktor-aktor poltik yang memanipulasi simbol-simbol adat dengan menginterpertasikan bahwa "Jou Kasa Ngom Kage" ini adalah iddin kolano atau perintah sultan. Yang ini coba dimainkan oleh aktor-aktor politik yang tidak bertanggungjawab. "Jou Kasa Ngom Kage" ini terbangun berdasarkan kepatuhan, ketaatan serta kecintaan masyarakat terhadap keagungannya.

Setiap generasi muda atau pemilih pemula tentunya mereka punya daya tarik tersendiri terhadap kandidat yang ada dan salah satunya adalah pengaruh tokoh-tokoh adat yang kharismatik serta pengaruh kuat dari tokoh- tokoh nasional yang dianggapnya mempunyai popularitas dibidang politik yang disenangi seluruh lapisan masyarakt indonesia yang ada seperti, Jokowi (Presiden RI) Presiden yang terkenal baik sebagai orang yang suka blusukan kemana-mana. Selain itu, indikator utama dan yang semestinya harus diperhatikan oleh masyarakat pemilih dalam momentum demokrasi saat ini yaitu tawaran program kerja atau visi misi itu sendiri sehingga kedepan nantinya yang di harapkan oleh masyarakat dari sebuah sistem demokrasi itu bisa terbangun dengan baik. Selain itu mereka (Pemilih pemula) juga lebih cenderung ikutikutan (iko rame) sekaligus faktor lingkungan yang tidak mendukung serta dipengaruhi oleh simbol-simbol kebudayaan berupa pengabdian, kepatuhan, serta ketaan masyarakat terhadap, "Jo'ou Kolano" atau sang sultan dengan slogan politik yang sering dimanipulasi oleh aktor-aktor poltik di saat menjelang pemilihan baik itu pilkada maupun pemilihan legislatif yaitu "Jou Kasa ngom Kage"( Melayu Ternate) yang artinya sultan di mana torang disitu.

Menurut salah satu barasumber bahwa masyarakat yang berada pada lingkaran adat umumnya telah tunduk dan patuh terhadap adat seatoran. Dalam hal politik masyarakat, lebih cenderung mengikuti Iddin Kolano atau perintah jo'ou (sultan), iddin kolano atau perintah jo'ou, ini diyakini sebagai perintah tuhan yang wajib 
hukumnya untuk dilaksanakan. Kolano merupakan pemimpin adat yang sakral yang diyakini sebagai wakil dari tuhan. Beliau menyebutnya sebagai, "primus interpares" atau pemimpin yang kharismatik itu adalah pemimpin yang terpercaya dan di hormati oleh rakyatnya. Di Kota Ternate dan bahkan sampai pada dataran halmahera kolano itu sangat dihormati dan dihargai sebagai pemimpin yang agung. olehnya itu dalam hal poltik, Kolano atau sultan itu merupakan figur sentral yang di tokohkan oleh rakyatnya. Hal ini terjardi karena beliau di interpetasikan sebagai manusia agung oleh rakyatnya dan ini merupakan sesuatu hal yang sakral dan tidak mudah dijelaskan oleh logika. Sehingga dalam dialog Ternate disebut macaou (pengabdian), yang tanpa dibayarpun mereka tetap tunduk dan patuh terhadap perintahnya.

Pemilih pemula ini ada dua kategori, kategori yang pertama adalah pemilih yang konvensional dan yang kedua adalah pemilih yang non- konvensinal. Pemilih pemula ia lebih cenderung mengikuti kemauan orang tua, keluarga serta teman dekat. Kalau pun ia mengikuti kemauannya sendiri terkecuali ia dibayar atau diberikan sesuatu oleh kandidat tertentu. Kalaupun tidak maka kandidat yang akan dipilih itu ia sekeluarga, kerabat serta etnis dengannya. Tidak tertarik soal partai atau visi misi yang disampaikan oleh kandidat maupun tim-tim sukses yang ada baginya kandidat yang banyak janjinya itu adalah kandidat yang banyak membodohi masyarakat dan lebih mementingkan kepentingan kelompoknya dibandingkan dengan kepentingan umum.Selaku generasi muda atau pemilih pemula tentunya ia punya prinsip dan pendirian tersendiri tanpa harus dipengaruhi oleh pihak mana pun, termasuk faktor lingkungan dan kebudayaan yang dianut oleh penduduk setempat. Apa lagi ini persoalan politik yang tentunya kita harus perhatikan betul soal latar belakang dari masing-masing kandidat yang bertarung pada pemilihan tersebut, termasuk tingkat pendidikan serta visi misi yang ditawarkan oleh kandidat yang bertarung nanti dan apakah ia pernah terjerat kasus hukum atau tidak? Sehingga kandidat yang kita berikan amanah itu benar-benar mampu dan siap untuk bekerja demi kepentingan rakyat.

\section{b. Bentuk-Bentuk Partisipasi Politik Pemilih Pemula}

Hasil temuan wawancara di lapangan menunjukkan bahwa terlepas dari tanggungjawab mereka (pemilih pemula) untuk memberikan hak suaranya pada pemilihan nanti mereka juga dapat ikut serta dalam kampanye politik yang diselenggarakan oleh masing-masing kandidat dan partai politik yang ada. Di samping itu, hasil temuan di lapangan juga menunjukkan bahwa kalau pemilihan kepala daerah seperti pilgub biasanya jauhjauh tempo sebelum pemilihan itu ia sudah diberitahu oleh orang tua untuk tidak boleh memilih orang yang itu bukan pilihan, $\mathrm{Ou}$ (sultan). Sementara untuk pemilihan legislatif kami sekeluarga itu pilih sultan untuk DPD-RI sesuai dengan brosur yang bertuliskan, TOPO NGORI (Melayu Ternate) yang artinya pilih saya. Hal ini mereka (pemilih pemula) lakukan semata- mata karena patuh terhadap orang tua dan katanya mereka takut kalau berbohong, sementara menurut Wade (Warga) ini merupakan bentuk pengabdian serta kecintaan mereka terhadap sang jo'ou kolano atau sultan dan mereka lakukan tanpa ada paksaan apapun.

Bentuk-Bentuk partisipasi politik pemilih pemula diikut sertakan dalam sosialisasi yang diselenggarakan oleh KPU, sosialisasi yang disampaikan oleh KPU ini dengan tujuan memberikan pengetahuan terkait dengan tata cara pemilihan dengan baik dan benar sesuai dengan asas-asas yang berlaku.oleh karena itu tanggungjawab mereka untuk memberikan hak suaranya pada pemilihan nanti mereka juga dapat ikut serta dalam kampanye politik yang diselenggarakan oleh masing-masing kandidat dan partai politik yang ada. Wawancara dengan Ermin (akademisi) beliau menjelaskan bahwa ada beberapa faktor-faktor yang turut mempengaruhi bentuk partisipasi pemilih pemula yakni sebagai berikut :

1) Faktor Keluarga (Patron Klien)

2) Faktor Lingkungan (Teman Sejawat)

3) Faktor Ekonomi

Lebih lanjut beliau menjelaskan bahwa partisipasi langsung adalah partisipasi yang terjadi apabila individu sebagai pemilih pemula menampilkan kegiatan-kegiatan tertentu dalam proses partisipasi seperti mereka ikut terlibat dalam kampanye politik, ikut serta dalam diskusi-diskusi politik atau debat kandidat serta terlibat secara langsung dalam menyalurkan hak suara. Menurut salah satu narasumber pemilihan kepala daerah seperti pilgub dan piwako biasanya jauh-jauh tempo sebelum pemilihan itu ia 
sudah diberitahu oleh orang tuanya untuk tidak boleh memilih orang yang itu bukan pilihan, $O u$ (sultan). Sementara untuk pemilihan legislatif kami sekeluarga itu pilih, $O u$ atau sultan untuk DPD-RI sesuai dengan brosur yang bertuliskan, topo ngori (Melayu Ternate) yang artinya 'pilih saya'. Hal ini mereka (pemilih pemula) lakukan semata-mata karena patuh terhadap perintah orang tua dan katanya mereka takut kalau berbohong, sementara menurut Wade (warga setempat) ini merupakan bentuk pengabdian serta kecintaan kami terhadap $\mathrm{Ou}$ atau sultan dan ini dilakukan tanpa ada paksaan apapun.

Hasil temuan di lapangan menunjukkan bahwa "Jou Kasa ngom Kage" (Melayu Ternate), yang artinya sultan dimana rakyatnya pun disitu sekalipun kita tahu bahwa hal ini tidak dilarang oleh undang-undang maupun peraturan KPU. Namun ini merupakan kendala besar bagi kami selaku pemilih-pemula di lain sisi kami sadar betul bahwa hajatan politik ini merupakan bagian dari proses demokrasi yang secara langsung memberikan ruang kepada masyarakat untuk menentukan pemimpin maupun wakil rakyat sesuai dengan hati nurani masing-masing tanpa harus ada intervensi atau keterwakilan dari pihak manapun. Serta memberikan pendidikan politik bagi masyarakat pemilih dan lebih khususnya bagi kami (pemilih pemula) untuk dapat menentukan pemimpin atau para wakil rakyat dengan baik dan sesuai dengan asas-asas demokrasi yang telah ada seperti kebebasan, jujur, serta keadilan dalam berdemokrasi, lemahnya sumber daya manusia (SDM) dan pengaruh dari lingkungan keluarga, teman sejawat dan ekonomi.

Selain itu kendala bagi pemilih pemua adalah biasanya mereka dibujuk dan dirayu dengan uang oleh para tim-tim sukses dari masing-masing kandidat dan partai politik yang ada untuk dapat memilih jagoan yang mereka andalkan baik dari partai politik maupun dari calon independen untuk anggota DPD-RI. Lebih lanjut menurutnya adat istiadat atau kebiasaan masyarakat setempat juga sangat berpengaruh untuk menarik simpatisan pemilih apalagi ditambah dengan pemanfaatan simbol-simbol adat untuk kepentingan politik seperti Jo'ou Kasa ngom Kage (Melayu Ternate), yang artinya 'sultan dimana rakyatnya pun disitu'.

\section{KESIMPULAN}

1. Partisipasi politik pemilih pemula di Kelurahan Kulaba Kecamatan Pulau Ternate pada pemilihan legislatif tahun 2014, masih cenderung didominasi oleh, kekuatan dan daya tarik para tokoh-tokoh adat yang kharismatik. Dimana figur yang kharismatik itu merupakan anugerah dari Sang Ilahi atau sebagai kekuatan yang tidak bisa dijelaskan oleh logika. Sehingga dalam momentum politik khususnya pemilihan legislatif tidak ada alasan bagi bala kusu (rakyat) untuk tidak memilih sang figur yang kharismatik maupun keluarga atau kerabat dekatnya.

2. Bentuk partisipasi politik pemilih pemula di Kelurahan Kulaba Kecamatan Pulau Ternate seperti terlihat dari keterlibatan pemilih pemula dalam kegiatan sosialisasi tahapan- tahapan pemilihan legislatif, keikutsertaan dalam kegiatan kampanye penyampaian visi misi partai politik sekaligus penyampaian visi misi calon anggota legislatif dan kehadiran mereka dalam memberikan hak suara pada saat pemilihan. "Jou kasa ngom kage" (melayu Ternate) yang artinya 'Jou'ou atau Sultan dimana, rakyatnya pun disitu', ini merupakan bahasa pers (Media) yang coba dimanipulasi oleh aktor-aktor politik disaat menjelang pemilihan baik itu pemilihan legislatif maupun pemilihan kepala Daerah dangan tujuan untuk mendapatkan dukungan dari masyarakat yang berada pada lingkaran kultur kesultanan. Bukan bahasa yang lahir bersamaan dengan lahirnya kerajaan kesultanan Ternate.

3. Kendala-kendala sebagai penghambat partisipasi politik pemilih pemula dalam menentukan hak pilihnya masih dipengaruhi oleh perilaku sebagian calon anggota legislatif yang memanipulasi simbol-simbol adat untuk kepentingan politiknya. Di samping itu pula masih minimnya tingkat pendidikan para pemilih pemula yang belum memiliki sikap kedewasaan dalam menentukan pilihannya sebagai warga negara yang bebas dalam menentukan pilihan politiknya.

\section{DAFTAR PUSTAKA}


Hasan Basahona dan Syahril, M. 2018. Political Participation, Beginner Voter, Legislative Election and Kulaba Village

Abdullah Rozali. (2009). Mewujudkan Pemilu yang Lebih Berkualitas (Pemilu Legislatif). Jakarta: Rajawali Pers

Ata Ujan Andre. (2001). Keadilan dan Demokrasi Telaah Filsafat Politik John Rawls. Yogyakarta: Kanisius Budiarjo, Miriam. (2009). Dasar-Dasar Ilmu Politik. Jakarta: Gramedia Pustaka Utama

Dove, Michael R. (Penyunting). (1988). Peran Kebudayaan Tradisional Indonesia dalam Modernisasi. Jakarta: yayasan Obor Indonesia.

Fahmi, Khairul. (2011). Pemilihan Umum dan Kedaulatan Rakyat. Raja Grafindo Persada. Jakarta.

Judistira, (1992). Pengembangan Nilai-Nilai Tradisional Berbasis Religius. Yogyakarta : Kanisius.

Kartono, Kartini. (2010). Pemimpin dan Kepemimpinan. Jakarta: Rajawali Pers

Leirissa R.Z.,(1996). Halmahera Timur dan Raja Jailolo Pergolakan di Laut Seram Abad Ke-19 (Jakarta: Balai Pustaka.

Muhammad, Syahril. (2013). Masyarakat Ternate”Pergulatan Tradisi dan Modernitas".'Yogyakarta: Ombak

Rivai, Veithzal, 2004, Kepemimpinan dan Perilaku Organisasi, Jakarta: PT. Raja Grafindo Persada

Sastroadmojo, Sudjiono. (1995). Partisipasi Politik. Semarang : IKIP Semarang Press.

Sutherland H, (1983). Terbentuknya Sebuah Elite Birokrasi, Jakarta: Sinar Harapan.

Syafiie, I. K. (2010). Ilmu Politik. Jakarta: Rineka Cipta.

Syarbaini, Syahrial. (2009). Implementasi Pancasila Melalui Pendidikan Kewarganegaraan. Jakarta: Graha Ilmu.

Trijono, L. (1996). Globalisasi Modernitas dan Krisis Negara-Bangsa: Tantangan Integrasi Nasional dalam Konteks Global. A. CSIS thn XXV No. 2. 96.

Weiner, M. (1982). Modernisasi : Dinamika Pertumbuhan. American: Forum Lectures.

William, Liddle. (1992). Partisipasi dan Partai Politik Indonesia pada Awal Orde Baru. Jakarta: Pustaka Utama Grafitri 